\title{
Distinguishing between Bos and Bison petrous bones. A case study: bovines from the Des-Cubierta Cave (Pinilla del Valle, Madrid)
}

\author{
María Á. GALINDO-PELLICENA ${ }^{1,2,3 *}$, Juan L. ARSUAGA ${ }^{1,4}$, César LAPLANA ${ }^{2}$, Ignacio DE \\ GASPAR ${ }^{5}$, Diego ÁLVAREZ-LAO ${ }^{6}$, Alfredo PÉREZ-GONZÁLEZ \& Enrique BAQUEDANO ${ }^{2,8}$
}

${ }^{1}$ Centro Mixto UCM-ISCIII de Evolución y Comportamiento Humanos. C/Monforte de Lemos 5, pab 14, 28029, Madrid, Spain; mariangape79@hotmail.com

${ }^{2}$ Museo Arqueológico Regional. Plaza de Las Bernardas s/n, 28801 Alcalá de Henares, Madrid; cesar.laplana@gmail.com, mangeles.galindo@fgua.es

${ }_{3}^{3}$ Fundación General de la Universidad de Alcalá de Henares. C/Imagen, 3, 28801 Alcalá de Henares; enrique.baquedano@madrid.org

${ }^{4}$ Departamento de Geodinámica. Estratigrafía y Paleontología Facultad de Ciencias Geológicas. Universidad Complutense de Madrid, Calle José Antonio Novais 12, 28040 Madrid, Spain; jlarfer@gmail.com

${ }^{5}$ Sección departamental de Anatomía y Embriología. Facultad de Veterinaria. Universidad Complutense de Madrid, Avda. Puerta del Hierro s/n. Ciudad Universitaria, 28040 Madrid, Spain; idegaspar@vet.ucm.es

${ }^{6}$ Departamento de Geología, Universidad de Oviedo, C/ Jesús Arias de Velasco s/n 33005 Oviedo, Spain; diego_alvarezlao@yahoo.es

${ }^{7}$ Unidad de Investigación Consolidada de la Junta de Castilla y León UIC 182. Centro Nacional de Investigación sobre la Evolución Humana (CENIEH). Paseo de Atapuerca, 3. 09002 Burgos, Spain; alfredopg41@hotmail.es

${ }^{8}$ Instituto de Evolución en África. Plaza de San Andrés 2, 28005. Madrid, Spain

*Corresponding author

Galindo-Pellicena, M.Á., Arsuaga, J.L., Laplana, C., De Gaspar, I., Álvarez-Lao, D., Pérez-González, A. \& Baquedano, E. 2019. Distinguishing between Bos and Bison petrous bones. A case study: bovines from the Des-Cubierta Cave (Pinilla del Valle, Madrid). [Discriminación taxonómica de Bison priscus y Bos primigenius a partir de la morfología del hueso petroso, en el yacimiento de Cueva Des-Cubierta (Pinilla del Valle, Comunidad de Madrid, España)]. Spanish Journal of Palaeontology, 34 (2), 257-268.

Manuscript received 12 December 2018

Manuscript accepted 24 May 2019 https://doi 10.7203/sjp.34.2.16115

(C) Sociedad Española de Paleontología ISSN 2255-0550

\section{ABSTRACT}

The taxonomic identification of large bovine remains in archaeological and palaeontological sites is important in order to infer the palaeoenvironment of these sites and to know if their inhabitants were hunters of Bos or Bison. Their presence may also have biostratigraphic or archaeozoological implications. Although the petrous bone is one of the elements of the skeleton with the greatest preservation potential in prehistoric sites, due to its hardness and compactness, it is not frequently used by the palaeontologists to distinguish between Bos and Bison, the two genera commonly present

\section{RESUMEN}

La identificación de grandes bovinos en yacimientos arqueológicos es primordial para inferir el paleoambiente de estos yacimientos y para conocer si los seres humanos que los habitaron cazaban Bos o Bison. Su presencia puede tener, además, implicaciones bioestratigráficas y zooarqueológicas. A pesar de que el hueso petroso es uno de los restos con mayor potencial de conservación en los yacimientos por su dureza y compacidad, los paleontólogos no suelen utilizarlo para discriminar entre Bos y Bison, los dos géneros de bovinos que más habitualmente se encuentran en los yacimientos 
at the sites during the Pleistocene. Due to the abundance of petrous bones at the Late Pleistocene layers of the DesCubierta cave, the aim of this work is to identify Bos and Bison in this site through the morphological features defined by Guadelli (1999) for this bone and using morphometric geometrics with material of Bos taurus, Bos primigenius, and Bison priscus in order to identify the differences among petrous bones of these species.

Keywords: Taxonomy, bovines, Pleistocene, petrous bone, Pinilla del Valle. pleistocenos. Debido a la abundancia de huesos petrosos que se encuentran en los niveles del Pleistoceno Superior de la cueva Des-Cubierta, el objetivo de este trabajo es diferenciar Bos y Bison en este yacimiento a partir de los criterios morfológicos definidos por Guadelli (1999) para este hueso y utilizar la morfometría geométrica con material de Bos taurus, Bos primigenius y Bison priscus para precisar las diferencias entre los petrosos de estas especies.

Palabras clave: Taxonomía, bovinos, Pleistoceno, petrosos, Pinilla del Valle.

\section{INTRODUCTION}

Bison priscus (Bojanus, 1825) (the steppe bison) and Bos primigenius Bojanus, 1825 (the modern cattle's - Bos taurus - ancestor) are two different species of bovines that coexisted in Europe during the Middle and the Late Pleistocene (Kurtén, 1968).

The steppe bison was one of the most abundant large mammals in the north of the Iberian Peninsula during the Late Pleistocene. It was frequently represented in this region in Upper Palaeolithic engravings and paintings (González Echegaray \& González Sáinz, 1994; Altuna $\&$ Mariezkurrena, 2014). The steppe bison, together with the mammoth and the woolly rhinoceros, is one of the main taxa represented in typical tundra-steppe wildlife associations, which feed on pastures in open landscapes (Guthrie, 1990; Sher, 1971; Brugal, 1985).

The aurochs (Bos primigenius Bojanus, 1825) is the unique ancestor of cattle livestock (Bos taurus Linnaeus, 1758) (Zeuner, 1963; Clutton-Brock, 1999). It inhabited the Iberian Peninsula from the Middle Pleistocene (Bos primigenius was found for the first time in Torralba and Ambrona sites, dated around $500 \mathrm{ka}$ : Soto et al., 2001) to the Holocene. The latest bone remains of this species have been found at the Roman sites from the Basque Country (Altuna \& Mariezkurrena, 2002). The aurochs probably inhabited in wet habitats, such as river valleys, lake fringes, marshy forests (Van Vuure, 2005) and open woodlands (Kurtén, 1968).

Although Bos and Bison did not have the same ecological preferences, they have been found together at some Iberian sites, in some cases in the form of engravings and paintings (e.g., Ekain, Altxerri; Altuna \& Mariezkurrena, 2014), and in other cases as associations of bone remains of both species (e.g., at the Lezetxki site and the Morín site; Altuna, 1972, and at the Búho and Zarzamora caves; Sala et al., 2010).

Assigning the large bovine remains from the Middle and Late Pleistocene sites to one of these species is complex because both species have a similar size and bone morphology. There is an extensive literature devoted to the distinction of Bos and Bison (Schertz, 1936; Bibikova, 1958; Stampfli, 1963; Sala, 1986; Altuna, 1972; Brugal, 1985; Gee, 1993; Buitrago-Villaplana, 1992; Prat et al., 2003; Sala et al., 2010; among others). The skeletal elements that allow us to better distinguish between the two species are the metacarpals and the skull (especially the horn cores, the frontals, parietals and occipitals) (Lavocat \& Piveteau, 1966). Nevertheless, these diagnostic bones are not represented at most sites or they are not well preserved enough to allow for an unequivocal identification. In these cases, the fossil remains are often grouped without distinction into the category "Bos/Bison".

In this context, the purpose of this contribution is to highlight the importance of the petrous bone as an element that can serve to identify the large bovines found at Iberian sites. The petrous bone is, along with the teeth, one of the skeletal elements with the greatest preservation potential in archaeo-palaeontological sites, due to their hardness and compactness (Lam et al., 1999; Bar-Oz \& Dayan, 2007) and constitutes one of the best anatomical elements for extracting DNA (Gamba et al., 2014). Some previous works have demonstrated the existence of morphological differences between the petrous bones of aurochs and steppe bison (Guadelli, 1999). In this work, these diagnostic criteria are applied to the identification of a relatively large sample of large bovine petrous bones from the Late Pleistocene levels of the Des-Cubierta cave site (Pinilla del Valle, Madrid) in order to confirm their validity by crossing the identifications obtained from the study of petrous bones with that of the identification of the partial skulls to which they belong.

The GM (geometric morphometrics) is applied for the analysis of shape of the internal auditory canal, which is considered a diagnostic element to distinguish Bos and Bison, according to Guadelli (1999).

\subsection{The site}

The Des-Cubierta site is one of the sites located at the Calvero de la Higuera in Pinilla del Valle (Community of 
Madrid) (Fig.1). It was discovered in 2009 and since then it has been the subject of annual excavations. It has a long stratigraphy that includes Middle and Late Pleistocene sediments.

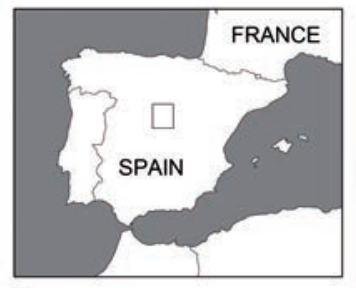

a
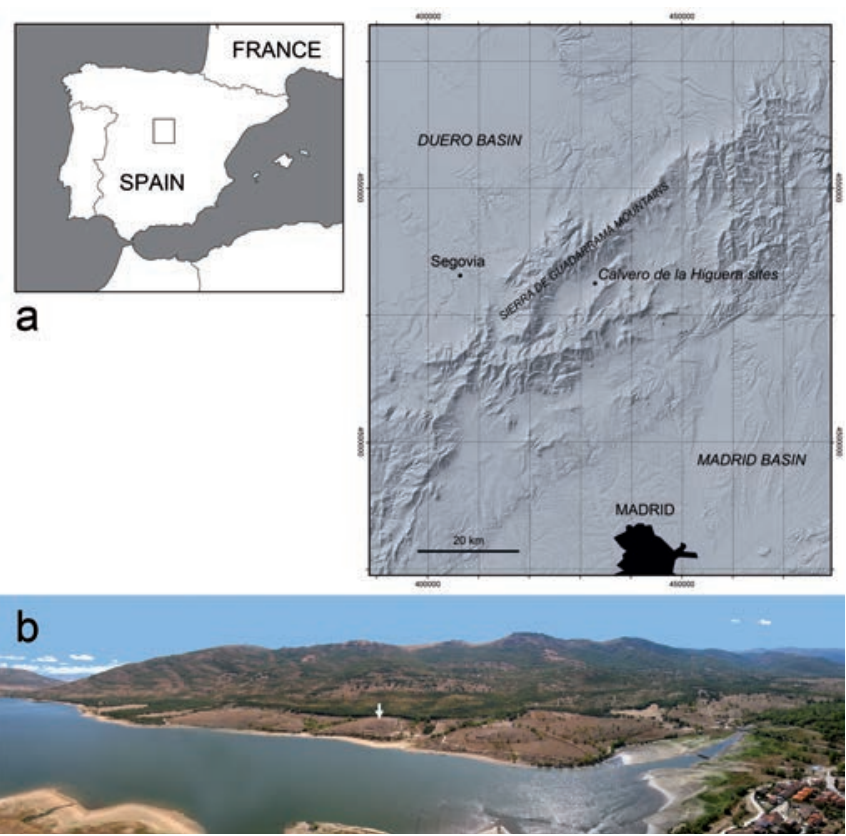

Figure 1. Location map of the Calvero de la Higuera archaeopalaeontological sites, among which Des-Cubierta cave is included.

The recovered bovine bones that have been studied in this work were found in the Late Pleistocene levels. A Homo neanderthalensis mandible and some teeth have been discovered in these levels (Rodríguez et al., 2016). Nevertheless, the most outstanding feature of these levels is the vast amount of partial crania of Bison priscus, Bos primigenius, Cervus elaphus, and Stephanorinus hemitoechus (Baquedano et al., 2016). At least 20 individuals of bovines have been identified using horn cores (the most abundant element). Most of the horn cores belong to Bison priscus (15 individuals) and only 2 horn cores belong to Bos primigenius ( 2 individuals), although the number of identified individuals is growing up as new excavation campaigns take place. In some cases in which the apexes are the only preserved part of the horn cores, the generic adscription of some individuals has not been possible. In order to determine the abundance of both taxa in this site, some cranial bones other than the horn cores can be used in the identification of bovine remains. The petrous bone is one of the best candidates. This element constitutes the auricular or tuberous portion of the temporal bone, and includes its tympanic part. Due to its preferential preservation with respect to other parts of the skeleton and the skull in particular for the reasons indicated above, numerous well-preserved petrous bones have been recovered at the site. Therefore, in this work, this bone is going to be used to identify these bovines.

\section{MATERIAL AND METHODS}

\subsection{The material}

The studied material is composed of 27 petrous bones: 16 petrous bones from Bovinae of the Pleistocene levels 1, 2, 5 and 101 from the Des-Cubierta cave site (Pinilla del Valle, Madrid) and 11 that belong to modern individuals of Bos taurus (Table 1). One petrous bone from DesCubierta cave, associated with its corresponding Bison priscus skull, and 11 that belong to modern Bos taurus have been used for comparison. Bos primigenius is the ancestor of modern cattle, Bos taurus, and, because petrous bones of aurochs are so difficult to find, the petrous bones of modern cattle have been used for the analysis. Seven of these come from the osteology collection of the Veterinary School's Anatomy and Embryology Department at the UCM (University Complutense of Madrid), two from the animal bone comparative collections of the UCM-ISCIII Center on Human Evolution and Behaviour (Madrid) and two from the animal bone comparative collection of the Regional Archaeological Museum in Alcalá de Henares.

In order to distinguish between Bos taurus, Bos primigenius and Bison priscus, 33 photos of medial faces of the petrous bone were used, according to the list included in Table 1. Different cameras were used in the taking of the images of the material from the Des-Cubierta cave: Sony DSC-H50; Nikon D500 and Nikon D810 (Mario Torquemada, Regional Archaeological Museum at Alcalá de Henares).

\subsection{Methodology}

In order to appreciate the morphology of petrosal bone in the skulls of present-day bovines, two skulls belonging to the collections of Anatomy and Embryology Department's laboratory at UCM's Veterinary School were cut longitudinally and prepared for study.

A complete morphological description, as well as metrical analyses, have been carried out from the different faces whenever possible, following the criteria defined by Guadelli (1999). The terminology used in the description of the different parts of the medial face from a bovine petrous bone is shown in Figure 2.

\subsubsection{Metrical analysis}

The metrical data have been taken using a Sylvac digital caliper (03.02/SYL-235-F, D, E/681.046-100) to the nearest 
Table 1. Petrous bones of bovines used for the study. * Bone remains used for the geometric morphometrics study.

\begin{tabular}{|c|c|c|c|c|c|}
\hline & Petrous bone & SIDE & Belonging to & Taxa & Come from \\
\hline $1 *$ & CDC10/I'41/1/29d & Right & Refiting to $\mathrm{CDC} 10 / \mathrm{G}^{\prime} 41 / 1 / 16 \mathrm{~b}$ & $X$ & CDC level1 \\
\hline $2 *$ & $\mathrm{CDC} 10 / \mathrm{G}^{\prime} 41 / 1 / 16 \mathrm{~b}$ & Left & Refiting to CDC10/I'41/1/29d & $\mathrm{X}$ & CDC level 1 \\
\hline $3 *$ & $\mathrm{CDC} 10 / \mathrm{H}^{\prime} 49 / 2 / 86$ & Right & & $\mathrm{X}$ & CDC level 2 \\
\hline $5 *$ & CDC10/I'41/1/29a & Left & Posible same individual of CDC10/I' $41 / 1 / 29 \mathrm{e}$ & $X$ & CDC level 1 \\
\hline $4 *$ & CDC10/I'41/1/29e & Right & Posible same individual of CDC10/I' $41 / 1 / 29 a$ & $\mathrm{X}$ & CDC level 1 \\
\hline 7 & CDC10/H'49/2/158 & Right & & $\mathrm{X}$ & CDC level 2 \\
\hline $8 *$ & $\mathrm{CDC} 12 / \mathrm{I} 40 / 101 / 36^{\mathrm{a}}$ & Right & & $\mathrm{X}$ & CDC level 101 \\
\hline $9 *$ & CDC12/I'39/101/11 & Left & & $\mathrm{X}$ & CDC level 101 \\
\hline $10^{*}$ & CDC12/J'38/101/68 & Right & & $\mathrm{X}$ & CDC level 101 \\
\hline $11 *$ & CDC13/J'37/101/20b & Right & & $\mathrm{X}$ & CDC level 101 \\
\hline $12 *$ & CDC13/I'39/101/6 & Right & & $\mathrm{X}$ & CDC level 101 \\
\hline $13 *$ & CDC14/I'36/251/18 & Right & & $\mathrm{X}$ & CDC level 251 \\
\hline $14^{*}$ & CDC15/K’39/101/87 & Left & & $\mathrm{X}$ & CDC level 101 \\
\hline $15^{*}$ & CDC15/J'39/101/185d & Right & & $\mathrm{X}$ & CDC15 level 101 \\
\hline $16^{*}$ & CDC17/K'38/101/19 & Right & Cranium 2’17 & Bison priscus & CDC level 101 \\
\hline $17 *$ & BtA & Left & & Bos taurus & UCM's Veterinary School \\
\hline $18 *$ & $\mathrm{BtA} 2$ & Right & & Bos taurus & UCM's Veterinary School \\
\hline $19 *$ & $\mathrm{BtB}$ & Left & & Bos taurus & UCM's Veterinary School \\
\hline $20 *$ & $\mathrm{BtB} 2$ & Right & & Bos taurus & UCM's Veterinary School \\
\hline $21 *$ & $\mathrm{BtC}$ & Right & & Bos taurus & UCM's Veterinary School \\
\hline $22 *$ & $\mathrm{BtD}$ & Left & & Bos taurus & UCM's Veterinary School \\
\hline $23 *$ & $\mathrm{BtD} 2$ & Right & & Bos taurus & UCM's Veterinary School \\
\hline $24 *$ & ISCIII comparative & Left & & Bos taurus & ISCIII \\
\hline $25^{*}$ & ISCIII comparative & Right & & Bos taurus & ISCIII \\
\hline $26^{*}$ & MAR comparative & Left & & Bos taurus & MAR \\
\hline $27 *$ & MAR comparative & Right & & Bos taurus & MAR \\
\hline $28 *$ & C-G.cB2 & Right & & Bos primigenius & Guadelli (1999) \\
\hline $29 *$ & Artenac & Right & & Bos primigenius & Guadelli (1999) \\
\hline $30 *$ & Livernon & Left & & Bos primigenius & Guadelli (1999) \\
\hline $31 *$ & C-G.cE & Left & & Bison sp. & Guadelli (1999) \\
\hline $32 *$ & C-G.c.R & Left & & Bison sp. & Guadelli (1999) \\
\hline $33 *$ & Unikote & Left & & Bison sp. & Guadelli (1999) \\
\hline $34 *$ & Actuel B.bison & Right & & Bison bison & Guadelli (1999) \\
\hline
\end{tabular}




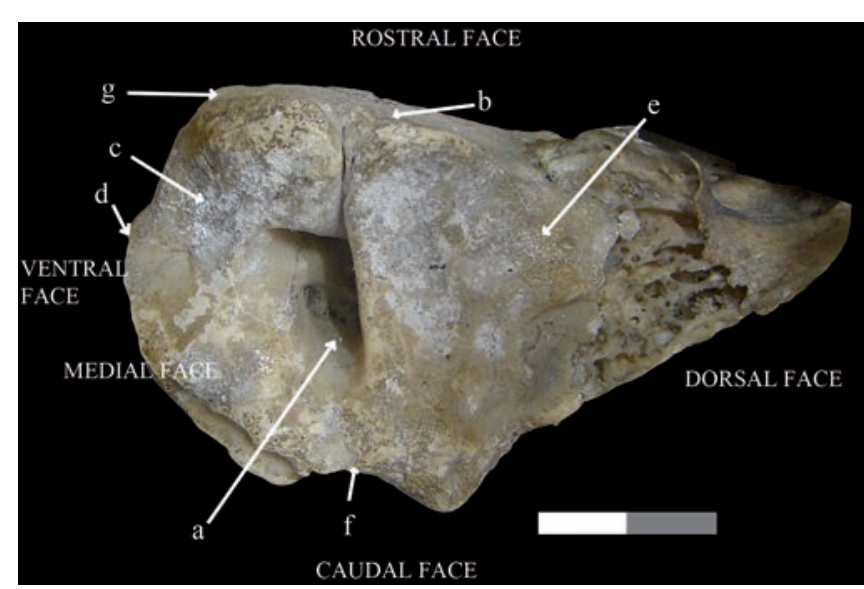

Figure 2. Bos taurus (comparative bovine from the UCM, Faculty of Veterinary). Medial view: a: internal acoustic meatus; b: petrosal crest; c: trigeminal nerve print; d: antero-inferior apex; e: cerebellar fossa; f: caudal crest; g: petrosal nerve hiatus.

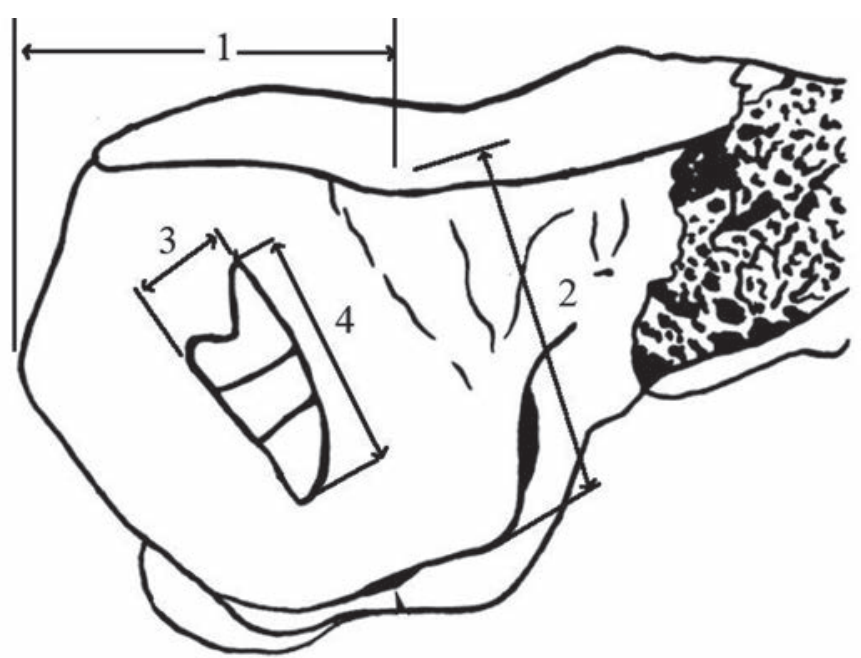

Figure 3. Metrical data of petrous bone: 1: dorso ventral diameter (Dvd); 2: rostro caudal diameter (Rcd); 3: dorso ventral diameter of internal acoustic meatus (DvdIAM); 4: rostro caudal diameter of internal acoustic meatus (RcdIAM), according to Mallet \& Guadelli (2013). Image modified from Guadelli (1999).

$0.01 \mathrm{~mm}$, following Mallet \& Guadelli (2013: Fig. 2) criteria, for the medial view (see Fig. 2 for nomenclature and Fig. 3 for measurements):

1) Dorso-ventral diameter (Dvd) (1): length between the antero-inferior apex and the ventral edge of the cerebellar fossa (measured on the rostral part of the fossa).

2) Rostro-caudal diameter (Rcd) (2): length between the edge of the petrous crest and the edge of the caudal crest (measured along the cerebellar fossa).
3) Dorso-ventral diameter of the internal auditory meatus (DvdIAM) (3): length of the meatus from one extremity to the other in the dorso-ventral direction.

4) Rostro-caudal diameter of the internal auditory meatus (RcdIAM) (4): length of the meatus from one extremity to the other in the rostro-caudal direction.

For each petrous bone, an attempt has been made to characterize its morphology according to the criteria that distinguish Bos primigenius from Bison priscus according to Guadelli (1999), which are the following:

1) On the medial face (Fig. 4), the internal acoustic meatus of Bison is more elongated than in Bos. In order to test this feature we have used an index: the ratio rostrocaudal diameter (4) with the dorso-ventral diameter (3) of the internal auditory meatus (Meatus acusticus internus). According to the internal canal description by Guadelli (1999), this index should be close to 1 for Bos and, further away from 1 and greater than 1 for Bison. The imprint of the trigeminal nerve (located between the antero-inferior apex and the petrous crest) is clearly concave in Bison, as opposed to Bos in which it is weakly concave or even almost rectilinear. The ventral part under the imprint of the trigeminal nerve does not protrude downwards in Bison (no salient towards the basis), whereas it clearly protrudes downwards in Bos (salient towards the basis).

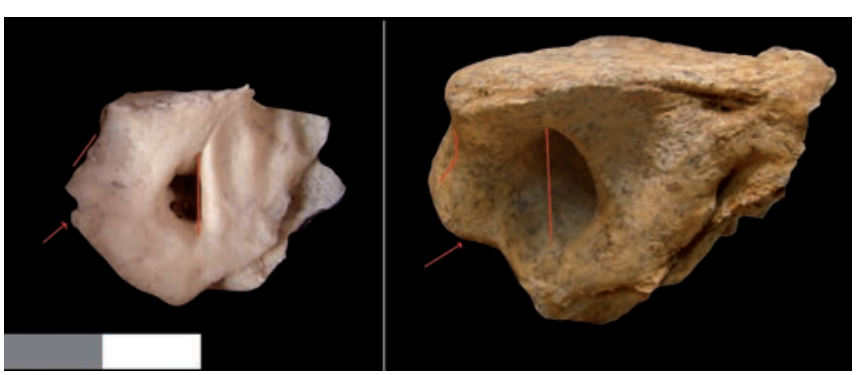

Figure 4. a) The medial face of petrous bone from Bos taurus (comparative bovine from UCM University, Faculty of Veterinary). b) The medial face of petrous bone from Bison priscus. The red arrow indicates the distinctive features from Bos and Bison.

2) The extent of the rostral face is very developed in Bovinae. In the case of Bison, the Fallopian hiatus hole (Canaliculus nervi petrosi majoris) is wide and a groove duct on the rostral surface of petrous bone is observed towards the ventral face. In Bos, the Fallopian hiatus opens directly downwards because it is not traversed by a groove (Fig. 5). Moreover, the rostral face is relatively more extensive in modern cattle than in aurochs.

3) The caudal face supports the basioccipital bone. In Bison the caudal face is regular. From back to front, a flat surface, a triangular depression, often wide and deep, and a small hole where a bone spine protruding from the occipital 


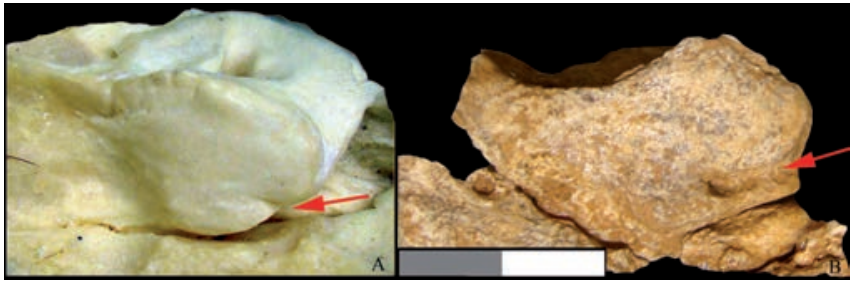

Figure 5. a) The rostral face of petrous bone from Bos taurus (comparative bovine from UCM University, Faculty of Veterinary). b) The rostral face of petrous bone from Bison priscus. The red arrow indicates no groove on Bos taurus and the groove on Bison priscus.

bone are observed. In Bos, it is irregular and undulating and there is no triangular depression like in Bison.

In all descriptions, the petrosal bone is considered to be in anatomical position, with the orientation relative to the Frankfort plane. This means that the cerebral face corresponds to the rostral face and the caudal face to the occipital face (according to the methodology from Mallet \& Guadelli, 2013).

\subsubsection{Geometric morphometrics}

For the taxonomical identification of Bos taurus, Bos primigenius, and Bison priscus, the 32 photos were used (the medial face of one petrous bone, CDC10/H'49/2/158a, was broken so it wasn't included for this analysis). Using geometric morphometrics, the internal auditory canal was analysed and 6 landmarks were defined (Fig. 6): Landmark 1: the rostro-ventral apex of the internal auditory canal; Landmark 2: the most rostral apex of the internal auditory canal; Landmark 3: the rostro dorsal apex of the internal auditory canal; Landmark 4: the caudo-dorsal apex of the internal auditory canal; Landmark 5: the most caudal apex

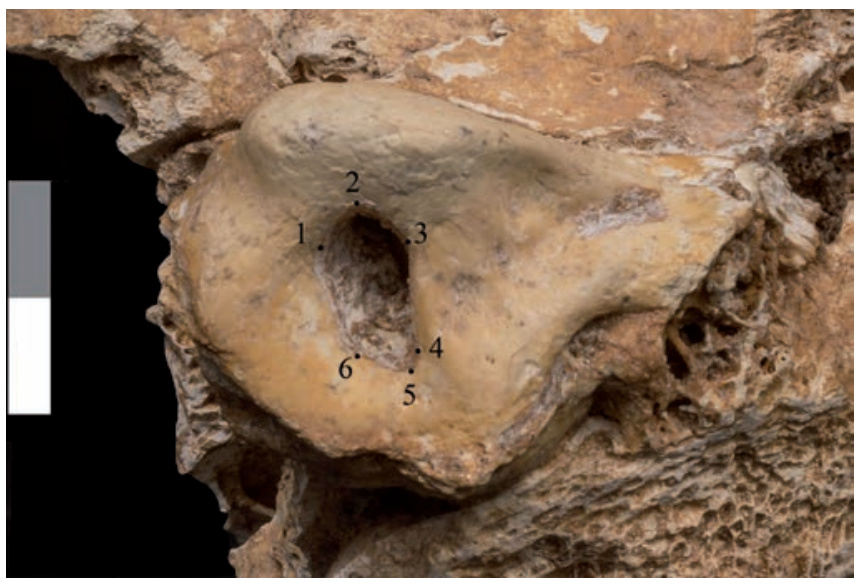

Figure 6. Landmarks defined in internal auditory canal. Photo taken by Alfonso Dávila. of the internal auditory canal; Landmark 6: the caudoventral apex of the internal auditory canal. The landmarks were digitalized using TpsDig v.2.17 (Rohlf, 2015). After digitizing all landmarks using TpsDig, the PCA analyses were performed using the MorphoJ v. 1.06d (Klingenberg, 2011).

\section{RESULTS}

\subsection{Osteological description}

\subsubsection{The medial or cerebellar face}

In Bos taurus, the trigeminal nerve imprint (Impressio nervi trigemini) is only very slightly concave and even completely flat. The index (4/3) that shows the shape of the internal auditory meatus (Meatus acusticus internus) is less than 1.6 (Table 3), which indicates the internal auditory meatus is not very elongated. In all cases of the Bos taurus petrous bones, a salient ventral-caudally is observed below the antero-inferior apex (Apex antero inferior partis petrosae).

In the bovines from Des-cubierta cave, the imprint of the trigeminal nerve (Impressio nervi trigemini) is concave in most cases of the fossil bone remains from the DesCubierta cave, except in CDC10/I'41/1/29a and CDC12/ I'40/101/36a, where the concavity is not so clear (Table 2). The index (4/3) of the internal auditory meatus is far from 1 , which indicates that the shape is elongated, according to the criteria observed by Guadelli (1999). The index $(4 / 3)$ is closer to 1 in three cases of the bone material from Des-Cubierta cave: CDC10/H'49/2/86, CDC10/I'41/1/29a, CDC10/I' $41 / 1 / 29$ e (see Table 3 ). This means that the internal auditory canal is not as elongated as in other fossil remains. No salient is observed below the antero-inferior apex in most of the cases.

\subsubsection{Osteometry}

In all cases of the petrous bones for the comparative modern cattle, the index $4 / 3$ is less than 1.6 (from 1.18 to 1.56 ) (Table 3). This indicates an internal auditory canal that is a bit elongated, according to the Guadelli (1999) criteria.

\subsubsection{Geometric morphometrics analysis of the internal auditory canal}

The PCA was performed on Bos taurus, Bos primigenius, and Bison priscus and the bovine petrous bones from Des-Cubierta cave (Fig. 7). The PC1 and PC2 explain respectively $56.88 \%$ and $18.39 \%$ of the total variance, thus explaining $75.27 \%$ of the shape variation within the sample. 
Table 2. Morphological characteristics of the petrous bone in medial face, according to Guadelli (1999).

\begin{tabular}{|c|c|c|c|c|}
\hline \multicolumn{5}{|c|}{ Medial face } \\
\hline & $\begin{array}{l}\text { Rostro-caudal } \\
\text { diameter (4) } \\
\text { of the internal } \\
\text { auditory canal }\end{array}$ & $\begin{array}{l}\text { Dorso- } \\
\text { ventral } \\
\text { diameter } \\
\text { (3) of the } \\
\text { internal } \\
\text { auditory } \\
\text { canal }\end{array}$ & $\begin{array}{l}\text { trigeminal } \\
\text { nerve print }\end{array}$ & $\begin{array}{l}\text { Ventral } \\
\text { part } \\
\text { of the } \\
\text { antero- } \\
\text { inferior } \\
\text { apex }\end{array}$ \\
\hline CDC10/I'41/1/29d & Elongated & Narrow & Concave & \\
\hline CDC10/G'41/1/16b & Elongated & Narrow & Concave & \\
\hline CDC10/H'49/2/86 & Triangular shape & Narrow & Concave & No salient \\
\hline CDC10/I'41/1/29a & Little elongated & & $\begin{array}{l}\text { Little } \\
\text { concave }\end{array}$ & Broken \\
\hline CDC10/I'41/1/29e & Little Elongated & Narrow & Concave & Broken \\
\hline CDC10/H'49/2/158 & Broken & & Concave & \\
\hline $\begin{array}{l}\text { CDC12/ } \\
I^{\prime} 40 / 101 / 36 a \\
\end{array}$ & Little elongated & & $\begin{array}{l}\text { Little } \\
\text { concave }\end{array}$ & Salient \\
\hline CDC12/I’39/101/11 & & & No visible & No salient \\
\hline CDC12/J'38/101/68 & Elongated & Narrow & Concave & No salient \\
\hline $\begin{array}{l}\text { CDC13/ } \\
\text { J'37/101/20b }\end{array}$ & Elongated & Narrow & Concave & No salient \\
\hline CDC13/I'39/101/6 & Elongated & Narrow & Concave & No salient \\
\hline CDC14/I’36/251/18 & Elongated & Narrow & Concave & No salient \\
\hline CDC15/K'39/101/87 & Elongated & Narrow & Concave & \\
\hline $\begin{array}{l}\text { CDC15/ } \\
\text { J'39/101/185d }\end{array}$ & Elongated & Narrow & Concave & No salient \\
\hline $\begin{array}{l}\text { CDC17/K'38/101/19 } \\
\text { (Fig.8A) }\end{array}$ & Elongated & Narrow & Concave & \\
\hline BtA & Little elongated & Wide & Straight & Salient \\
\hline BtA2 & Litte elongated & Wide & Straight & Salient \\
\hline $\mathrm{BtB}$ & Little elongated & Wide & Straight & Salient \\
\hline BtB2 & Little elongated & Wide & Straight & Salient \\
\hline $\mathrm{BtC}$ & Little elongated & Wide & Straight & Salient \\
\hline $\mathrm{BtD}$ & Little elongated & Wide & Straight & Salient \\
\hline BtD2 & Little elongated & Wide & Straight & Salient \\
\hline ISCIII comparative & Little elongated & Wide & Straight & Salient \\
\hline ISCIII comparative & Little elongated & Wide & Straight & Salient \\
\hline MAR comparative & Little elongated & Wide & Straight & Salient \\
\hline MAR comparative & Little elongated & Wide & Straight & Salient \\
\hline
\end{tabular}

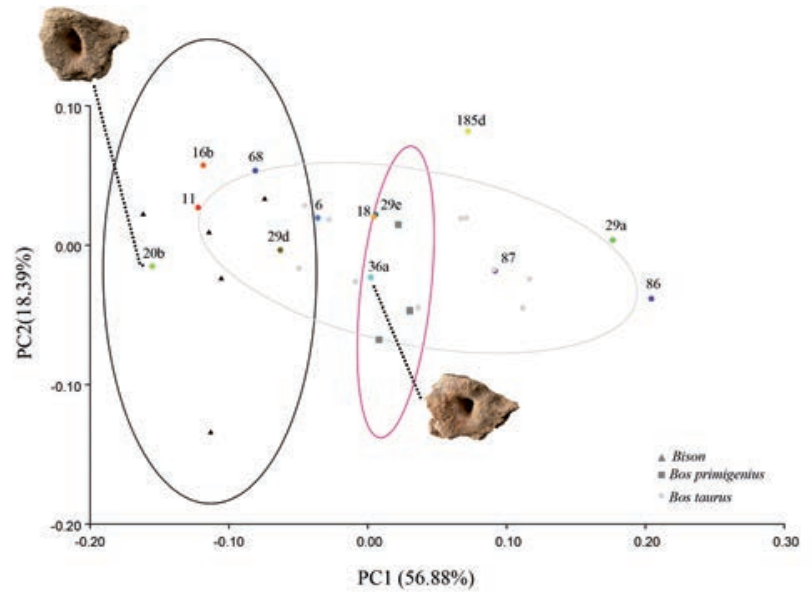

Table 3. Metrical data of the current petrous bones of Bos taurus (from UCM Veterinary Faculty): BtA; BtA2; BtB; BtB2; BtC; BtD; BtD2; BtISCIII; BtMAR and the petrous bone of Des-cubierta cave. The measurements have been taken according to Mallet and Guadelli (2013). CDC10/I'41/1/29a and CDC10/I'41/1/29e seem to belong to the same individual.

\begin{tabular}{|c|c|c|c|c|c|c|}
\hline $\begin{array}{l}\text { Taxonomical } \\
\text { identification }\end{array}$ & Medial view & 1 & 2 & 3 & 4 & $4 / 3$ \\
\hline Bos taurus & BtA & 27.55 & 24.22 & 7.7 & 9.1 & 1.18 \\
\hline Bos taurus & BtA2 & 28 & 26.5 & 6.4 & 9.9 & 1.54 \\
\hline Bos taurus & BtB & 28.07 & 24.03 & 5.6 & 8.4 & 1.5 \\
\hline Bos taurus & BtB2 & 28.3 & 24.6 & 5.8 & 9.08 & 1.56 \\
\hline Bos taurus & $\mathrm{BtC}$ & 25.23 & 22.2 & 5.7 & 8.7 & 1.52 \\
\hline Bos taurus & $\mathrm{BtD}$ & 25.4 & 26.6 & 7.2 & 11.3 & 1.56 \\
\hline Bos taurus & BtD2 & 24.21 & 26.13 & 8.29 & 10.67 & 1.28 \\
\hline Bos taurus RIGHT & ISCIII comparative & 23.8 & 27.4 & 5.7 & 8.6 & 1.51 \\
\hline Bos taurus LEFT & ISCIII comparative & 26.5 & 27.4 & 5.7 & 6.9 & 1.21 \\
\hline Bos taurus RIGHT & MAR comparative & 28.2 & 26.8 & 5.9 & 8.21 & 1.39 \\
\hline Bos taurus LEFT & MAR comparative & 27.15 & 25.11 & 7.4 & 8.11 & 1.09 \\
\hline Bison priscus & CDC15/K’39/101/87 & 30.4 & 26.4 & 6.25 & 11.35 & 1.82 \\
\hline - & $\begin{array}{l}\text { CDC15/ } \\
\text { J'39/101/185d }\end{array}$ & 29.8 & 28 & 5.9 & 11.5 & 1.95 \\
\hline - & CDC17/K’38/101/19 & 25.04 & 23.86 & 6.28 & 10.18 & 1.62 \\
\hline - & CDC10/I'41/1/29d & 21.97 & 26.25 & 7.2 & 11.8 & 1.64 \\
\hline - & $\mathrm{CDC} 10 / \mathrm{G}^{\prime} 41 / 1 / 16 \mathrm{~b}$ & 23.26 & 24.6 & 7.2 & 11.67 & 1.62 \\
\hline - & $\mathrm{CDC} 10 / \mathrm{H}^{\prime} 49 / 2 / 86$ & 20.06 & 19.7 & 6.7 & 10.06 & 1.50 \\
\hline- & CDC10/I'41/1/29a & 27.1 & 23.8 & 8.26 & 11.4 & 1.38 \\
\hline - & CDC10/I' $41 / 1 / 29 \mathrm{e}$ & 24.45 & 19.9 & 7.17 & 10.8 & 1.51 \\
\hline - & CDC10/H'49/2/158 & Broken & & & & \\
\hline - & CDC12/I' $40 / 101 / 36^{\mathrm{a}}$ & 25.17 & 26.09 & 5.34 & 8.7 & 1.63 \\
\hline - & CDC12/I'39/101/11 & 28.22 & 21.95 & 6.2 & 10.19 & 1.64 \\
\hline - & $\mathrm{CDC} 2 / \mathrm{J}^{\prime} 38 / 101 / 68$ & 24.8 & 22.7 & 6.8 & 11.7 & 1.72 \\
\hline - & $\begin{array}{l}\text { CDC13/ } \\
\text { J'37/101/20b }\end{array}$ & 19.09 & 22.33 & 5.93 & 11.29 & 1.90 \\
\hline - & CDC13/I'39/101/6 & 23.86 & 21.81 & 4.2 & 9.78 & 2.33 \\
\hline - & CDC14/I'36/251/18 & 19.21 & 19.18 & 6.7 & 11.22 & 1.67 \\
\hline
\end{tabular}

Figure 7. Results of PCA, where data from landmarks of petrous bones from Des-Cubierta cave are included. 11: CDC12/I'39/101/11; 16b: CDC10/G'41/1/16b; 18: CDC14/I'36/251/18; 185d: CDC15/J'39/101/185d; 20b: CDC13/J'37/101/20b; 29a: CDC10/I'41/1/29a; 29d: CDC10/I'41/1/29d; 29e: CDC10/I'41/1/29e; 36a: CDC12/I40/101/36a; 6: CDC13/I'39/101/6; 68: CDC12/J'38/101/68; 86: CDC10/H'49/2/86; 87: CDC15/K'39/101/87. Photos taken by Mario Torquemada (M.A.R.). 
The variation expressed by the $\mathrm{PC} 1$ showed differences in the width of the internal auditory canal between Bos taurus, Bison priscus, and Bos primigenius. These differences are illustrated in the Figure 7. In general, the internal auditory canal in Bos taurus is wider than in Bison priscus. The internal auditory canal of Bos primigenius is wider than Bison and included within the range of variability of Bos taurus. Nevertheless, the width of the internal auditory canal for Bison priscus does not overlap with the width for Bos primigenius (Table 3).

Accordingly (Fig. 7) seven of the 15 petrous bone remains from Des-Cubierta cave fall within the ellipse of Bison priscus. Three samples fall within the ellipse of Bos primigenius and four samples are closer to the ellipse of Bos taurus and Bos primigenius than Bison priscus.

\subsubsection{The rostral face (Table 4)}

In Bos taurus, on the rostral face, the Fallopian hiatus opens directly downwards. No groove from the Fallopian hiatus is observed.

Table 4. Morphological characteristics of the petrous bone in the rostral face, according to Guadelli (1999).

\begin{tabular}{|c|c|c|}
\hline & Fallopian hiatus canal & Groove \\
\hline CDC10/I'41/1/29d & Wide & To ventral face \\
\hline CDC10/G'41/1/16b & Wide & To ventral face \\
\hline $\mathrm{CDC} 10 / \mathrm{I}^{\prime} 41 / 1 / 29^{\mathrm{a}}$ & Relatively wide & It is not clear \\
\hline CDC10/I'41/1/29e & Relatively wide & It is not clear \\
\hline CDC10/H'49/2/158 & Wide & To ventral face \\
\hline CDC12/I' $40 / 101 / 36^{a}$ & & To ventral face \\
\hline CDC10/H'49/2/86 & Wide & To ventral face \\
\hline CDC12/J'38/101/68 & Wide & To ventral face \\
\hline CDC13/I'39/101/6 & & To ventral face \\
\hline $\begin{array}{l}\text { CDC13/ } \\
\text { J'37/101/20b }\end{array}$ & & To ventral face \\
\hline CDC14/I'36/251/18 & & To ventral face \\
\hline CDC15/K’39/101/87 & & To ventral face \\
\hline $\begin{array}{l}\text { CDC15/ } \\
\text { J'39/101/185d }\end{array}$ & & To ventral face \\
\hline CDC17/K'38/101/19 & Wide & To ventral face (Fig. 8b) \\
\hline $\mathrm{BtA}$ & \multicolumn{2}{|c|}{ Opens directly to ventral face: no groove } \\
\hline BtA2 & \multicolumn{2}{|c|}{ Opens directly to ventral face: no groove } \\
\hline $\mathrm{BtB}$ & \multicolumn{2}{|c|}{ Opens directly to ventral face: no groove } \\
\hline $\mathrm{BtB} 2$ & \multicolumn{2}{|c|}{ Opens directly to ventral face: no groove } \\
\hline $\mathrm{BtC}$ & \multicolumn{2}{|c|}{ Opens directly to ventral face: no groove } \\
\hline BtD & \multicolumn{2}{|c|}{ Opens directly to ventral face: no groove } \\
\hline $\mathrm{BtD} 2$ & \multicolumn{2}{|c|}{ Opens directly to ventral face: no groove } \\
\hline ISCIII comparative & \multicolumn{2}{|c|}{ Opens directly to ventral face: no groove } \\
\hline ISCIII comparative & \multicolumn{2}{|c|}{ Opens directly to ventral face: no groove } \\
\hline MAR comparative & \multicolumn{2}{|c|}{ Opens directly to ventral face: no groove } \\
\hline MAR comparative & \multicolumn{2}{|c|}{ Opens directly to ventral face: no groove } \\
\hline
\end{tabular}

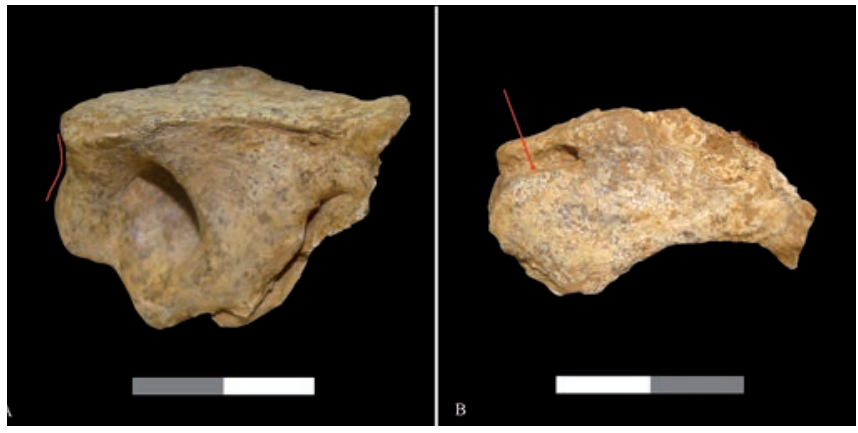

Figure 8. CDC17/K'38/101/19. This petrous bone belongs to an individual of Bison priscus. Medial (a) and rostral (b) faces are observed. In red, some diagnostic features are remarked: the concavity of the trigeminal nerve print (in picture a) and petrosal nerve hiatus (Fallopian hiatus canal) is wide and arrives to the ventral face.

The Fallopian hiatus hole is wide and there is a groove opening towards the ventral face in most petrous bones from the bovines of Des-Cubierta cave. This is a typical characteristic of Bison, according to Guadelli (1999).

\subsubsection{The caudal face (Table 5)}

In Bos taurus, the caudal face has not been morphologically described due to the lack of visibility of this face because all cattle petrous bones were connected to their skulls.

In most cases of the bovines from the Des-Cubierta cave, a flat surface following a triangular depression is observed. A small hole is present in almost all of the petrous bones.

Table 5. Morphological characteristics of the petrous bone in the caudal face, according to Guadelli (1999).

\begin{tabular}{lll}
\hline Caudal face & & \\
\hline & Surface & Depression \\
\hline CDC10/I'41/1/29d & This face isn't visible & \\
\hline CDC10/G'41/1/16b & Regular & Triangular and deep \\
\hline CDC10/H'49/2/86 & Regular & $\begin{array}{l}\text { A bone spine } \\
\text { is observed in } \\
\text { basioccipital bone }\end{array}$ \\
\hline CDC10/I'41/1/29a & $\begin{array}{l}\text { Irregular and } \\
\text { mountainous }\end{array}$ & No depression \\
\hline CDC10/I'41/1/29e & $\begin{array}{l}\text { Irregular and } \\
\text { mountainous }\end{array}$ & No depression \\
\hline CDC10/H'49/2/158 & No visible: is broken & \\
\hline CDC12/I'40/101/36 & Regular & Triangular and deep \\
\hline CDC12/I'39/101/11 & & \\
\hline CDC12/J'38/101/68 & No visible & Triangular and deep \\
\hline CDC13/J'37/101/20b & Regular & Triangular and deep \\
\hline CDC13/I'39/101/6 & Regular & Triangular and deep \\
\hline CDC14/I'36/251/18 & Regular & \\
\hline CDC15/K'39/101/87 & No visible & Triangular and deep \\
\hline CDC15/J'39/101/185d & Regular & Triangular and deep \\
\hline CDC17/K'38/101/19 & Regular &
\end{tabular}




\section{DISCUSSION AND CONCLUSSIONS}

In the medial face, the index (4/3) for the internal auditory canal is less than 1.6 in all cases for Bos taurus and larger than 1.6 in most cases of the petrous bone remains from Des-Cubierta cave (Table 3).

Using geometric morphometrics for the medial face, we can see that, in general, the internal auditory canal in Bos taurus is wider than in Bison priscus, in agreement with the criteria proposed by Guadelli (1999). The internal auditory canal width for Bos primigenius is included within the metrical range for Bos taurus. There is no overlap between the internal auditory canal width for Bos primigenius and Bison priscus. According to the analysis, there are no other shape differences, since the most determining variables are width and length.

In seven of the 15 petrous bone remains from DesCubierta cave, both the morphological features and the geometric morphometrics analysis indicate that these belong to Bison priscus (Table 6). In 2 cases, CDC10/ I'41/1/29a and CDC10/I'41/1/29e (possible same individual), both the morphological features and the GM analysis indicate that they belong to Bos primigenius. In five cases, the morphological features do not concur with the MG analysis and, thus, these petrous bones are classified as Bos/Bison. The morphological features of CDC10/H'49/2/158a suggests that it belongs to Bison priscus but the MG analysis could not be carried out because the bone is broken.

Table 6. Taxonomical classification according to the results obtained in this study.

\begin{tabular}{|c|c|c|c|c|}
\hline Level & Label & $\begin{array}{c}\text { Morphological } \\
\text { features }\end{array}$ & MG & $\begin{array}{l}\text { Taxonomical } \\
\text { identification }\end{array}$ \\
\hline \multirow{4}{*}{1} & CDC10/I'41/1/29d & Bison & Bison & Bison \\
\hline & $\mathrm{CDC} 10 / \mathrm{G}^{\prime} 41 / 1 / 16 \mathrm{~b}$ & Bison & Bison & Bison \\
\hline & CDC10/I'41/1/29a & Bos prim & $\begin{array}{l}\text { Bos } \\
\text { prim }\end{array}$ & Bos prim \\
\hline & CDC10/I'41/1/29e & Bos prim & $\begin{array}{l}\text { Bos } \\
\text { prim }\end{array}$ & Bos prim \\
\hline \multirow{2}{*}{2} & CDC10/H'49/2/86 & Bos/Bison & Bos & Bos \\
\hline & CDC10/H'49/2/158a & Bison & - & Bison \\
\hline \multirow{8}{*}{101} & $\begin{array}{l}\text { CDC12/ } \\
\text { I'40/101/36a }\end{array}$ & Bos/Bison & Bos & Bos/Bison \\
\hline & CDC12/I'39/101/11 & Bison & Bison & Bison \\
\hline & CDC12/J'38/101/68 & Bison & Bison & Bison \\
\hline & $\begin{array}{l}\text { CDC13/ } \\
\text { J'37/101/20b }\end{array}$ & Bison & Bison & Bison \\
\hline & CDC13/I'39/101/6 & Bison & Bison & Bison \\
\hline & CDC15/K'39/101/87 & Bison & Bos & Bos/Bison \\
\hline & $\begin{array}{l}\text { CDC15/ } \\
\text { J'39/101/185d }\end{array}$ & Bison & Bos & Bos/Bison \\
\hline & CDC17/K'38/101/19 & Bison & Bison & Bison \\
\hline 251 & CDC14/I'36/251/18 & Bison & $\begin{array}{l}\text { Bos/ } \\
\text { Bison }\end{array}$ & Bos/Bison \\
\hline
\end{tabular}

Therefore, the morphological characteristics established by Guadelli (1999) for the distinction of the petrous bones between Bos primigenius and Bison priscus agree in most of the analysed cases the results of the geometric morphometric analysis of the internal auditory canal. The petrous bones that correspond with the Bison features according to Guadelli (1999) support the previous taxonomical identification through horn cores and crania of bovines from the Des-Cubierta cave.

The different features seem to clearly separate the petrosa in different groups. The internal auditory canal analysis with geometric morphometrics for Bos taurus, Bos primigenius, and Bison priscus suggests that this structure tends to be wider in Bos primigenius than in Bison priscus, in agreement with the criteria defined by Guadelli (1999). We can see there is no overlap between them; nevertheless, the data must be taken with caution, due to the scarcity of the sample.

Finally, this study demonstrates the possibility of taxonomically identifying Bos and Bison from one of the bones with the greatest preservation potential in the archaeo-palaeontological sites, and which until now is rarely taken into consideration.

\section{ACKNOWLEDGEMENTS}

This research has been supported by the financial assistance of the Spanish Society of Palaeontology ID AJISEP-2017-07142. M.A. Galindo-Pellicena was also being supported by a postdoctoral grant from the Fundacion Atapuerca. We thank the Excavation Team of the DesCubierta cave for their work in the field, and our colleagues from the Centro Mixto UCM-ISCIII of Madrid and from the Regional Archaeological Museum of Alcalá de Henares, especially to Belén Márquez, Elena Santos, Beatrice Vacca and Abel Moclánfor their suggestions during the elaboration of the manuscript. Thanks must be extended to the Restoration Team, especially to M. Cruz Ortega, to the photographers Alfonso Dávila and Mario Torquemada (M.A.R.), Sandra Gómez and Lucía Villaescusa, as well as to the reviewers Joan Madurell and Johannes van der Made, and to the editor Carlos Martínez, for their suggestions that have greatly improved the manuscript. This work is a contribution to the project PGC2018-094125-B-100 (MCIU/ AEI/FEDER, UE) and PGC2018-093925-B-C33.

\section{REFERENCES}

Altuna, J. 1972. Fauna de mamíferos de los yacimientos prehistóricos de Guipúzcoa. Con catálogo de los 
mamíferos cuaternarios del Cantábrico y del Pirineo occidental. Munibe, 25, 1-464.

Altuna, J. \& Mariezkurrena, K. 2002. El problema de la domesticación de bovinos en el País Vasco y resto de la Región Cantábrica. Congresos de Estudios Vascos, 15, 123-128.

Altuna, J. \& Mariezkurrena, K. 2014. El Arte Rupestre Paleolítico en el País Vasco. Servicio Central de Publicaciones del Gobierno Vasco, Vitoria-Gasteiz.

Baquedano, E., Arsuaga, J.L., Pérez-González, A., Márquez, B., Laplana, C., Ortega, M.C., Huguet, R., Poza-Rey, E.M., Rodríguez, L., Alonso, J.I., Ortega, A.I., GalindoPellicena, M., García, N. \& Alvarez-Lao, D. 2016. The DesCubierta Cave (Pinilla del Valle, Comunidad de Madrid, Spain): a Neanderthal site with a likely funerary/ritualistic connection. European Society for the study of Human Evolution 6th Annual Meeting. Madrid. p.41.

Bar-Oz, G. \& Dayan, T. 2007. FOCUS: on the use of the petrous bone for estimating cranial abundance in fossil assemblages. Journal of Archaeological Science, 34, 13561360; doi: 10.1016/j.jas.2006.10.021.

Bibikova, V.I. 1958. Some distinguishing features in the bones of the genera Bison and Bos. Bull. Mosk. Obschtschestwa Isp Privoda NS Otdel Biol, 63, 23-35.

Bojanus, L.H. 1825. De uro nostrato ejusque sceleto commentatio Bovis primigenii sceleto aucta. Palaeontology Library of Muséum National d'Histoire Naturelle in Paris.

Brugal, J.P. 1985. Le Bos primigenius Bojanus, 1827 du Pléistocène moyen des grottes de Lunel-Viel (Hérault). Bulletin du Musée d'Anthropologie Préhistorique de Monaco, 28, 7-62.

Buitrago-Villaplana, A.M. 1992. Estudio de los artiodáctilos del yacimiento del Pleistoceno Medio de Pinilla del Valle (Madrid). Ph.D. Thesis, Universidad Complutense de Madrid.

Clutton-Brock, J. 1999. A Natural History of Domesticated Mammals. $2^{\text {nd }}$ ed. Cambridge University Press. Cambridge.

Gamba, C., Jone, E.R., Teasdale, M.D., McLaughlin, R.L., González-Fortes, G., Mattiangeli, V., Domboróczki, L., Kóvári, I., Pap, I., Anders, A., Whittle, A., Dani, J., Raczky, P., Higham, T.F.G., Hofreiter, M., Bradley, D.G. \& Pinhasi, R. 2014. Genome flux and statis in a five millennium transect of European prehistory. Nature Communications, 5, 1-9; doi: 10.1038/ncomms6257.

González Echegaray, J. \& González Sáinz, C. 1994. Conjuntos rupestres paleolíticos de la cornisa cantábrica. Complutum, $5,21-43$.

Gee, H. 1993. The distinction between postcranial bones of Bos primigenius Bojanus, 1827 and Bison priscus Bojanus, 1827 from the British Pleistocene and the taxonomic status of Bos and Bison. Journal of Quaternary Science, 8, 79-92; doi: 10.1002/jqs.3390080107.

Guadelli, J.-L. 1999. Quelques clés de détermination des portions pétreuses de temporal de(s) bison(s). Comparaison avec les rochers de Bos. In: Le Bison: Gibier et Moyen de Subsistance des Hommes du Paléolithique aux Paléoindiens des Grandes Plaines (eds. Brugal, J.-Ph., David, F., Enloe, J.G. \& Jaubert. J.). Actes du Colloque International. 51-62.
Guthrie, R.D. 1990. Steppe Bison Ecology and Phylogeny. Frozen Fauna of the Mammoth Steppe: the Story of Blue Babe. The University of Chicago Press, Chicago.

Klingenberg, C.P. 2011. MorphoJ: An integrated software package for geometric morphometrics. Molecular Ecology Resources, 11, 353-357; doi: 10.1111/j.17550998.2010.02924.x.

Kurtén, B. 1968. Pleistocene Mammals of Europe. Ed. Aldine, Chicago.

Lam, Y.M., Chen, X. \& Pearson, O.M. 1999. Intertaxonomic variability in patterns of bone density and the differential representation of bovid, cervid, and equid elements in the archaeological record. American Antiquity, 64, 343-362; doi: $10.2307 / 2694283$.

Lavocat, R. \& Piveteau, J. 1966. Atlas de Préhistoire 3. Faunes et Flores Préhistoriques de l'Europe Occidentale. L'Homme et ses Origines. Ed. Boubée Cie, París.

Linnaeus, C. 1758. Systema Naturae per Regna Tria Naturae, Secundum Classes, Ordines, Genera, Species, cum Characteribus, Differentiis, Synonymis, Locis. Laurentii Salvii, Holmiae. Vol. Tomus I, Editio decima, reformata: i-ii, $1-824$.

Mallet, C. \& Guadelli, J.-L. 2013. Distinctive features of Ovis aries and Capra hircus petrosal parts of temporal bone: Applications of the features to the distinction of some other Caprinae (Capra ibex, Rupicapra rupicapra). Paleo. Revue d'Archéologie Préhistorique, 24, 173-191.

Prat, F., Delpech, F., Cancel, N., Guadelli, J.L. \& SlottMoller, R. 2003. Le Bison des steppes, Bison priscus Bojanus, 1827, de la grotte d'Habarra à Arudy (PyrénéesAtlantiques). Paleo. Revue d'Archéologie Préhistorique, 15, 1-102.

Rodríguez, L., Quam, R., García-González, R., Poza-Rey, E.M., Pérez-González, A., Baquedano, E. \& Arsuaga, J.L. 2016. Neanderthal remains from Pinilla del Valle (Madrid, Spain). In: European Society for the study of Human Evolution 6th Annual Meeting. Madrid. 206.

Rohlf, F.J. 2015. The tps series of software. Hystrix, the Italian Journal of Mammology, 26, 9-12; doi: 10.4404/ hystrix-26.1-11264.

Sala, B. 1986. Bison schoetensacki Freud, from Isernia la Pineta (early Mid-Pleistocene- Italy) and revision of the European species of Bison. Palaeontographia Italica, 74, 113-170.

Sala, M.T.N., Pantoja, A., Arsuaga, J.L. \& Algaba, M. 2010. Presencia de bisonte (Bison priscus Bojanus, 1827) y uro (Bos primigenius Bojanus, 1827) en las cuevas del Búho y de la Zarzamora (Segovia, España). Munibe (Antropologia-Arkeologia), 61, 43-55.

Schertz, E. 1936. Zur Unterscheidung von Bison priscus Boj. und Bos primigenius Boj. and Metapodien un Astragalus. Senckenbergiana, 18, 37-71.

Sher, A.V. 1971. Mammals and stratigraphy of the Pleistocene of the extreme Northeast of the USSR and North America. Moscow, Nauka. International Geology Review, 16, 1-284.

Soto, E., Sesé, C., Pérez-González, A. \& Santonja, M. 2001. Mammal fauna with Elephas (Palaeoloxodon) antiquus from the lower levels of Ambrona (Soria, Spain). In: The 
World of Elephants: Proceedings of the $1^{\text {st }}$ International Congress (eds. Cavarretta, G., Giola, P., Mussi, M. \& Palombo, M.R.). Consiglio Nazionale delle Ricerche, Roma. 607-610.

Stampli, H.R. 1963. Wisent, Bison bonasus (Linné) 1758, Ur, Bos primigenius Bojanus, 1827, und Hausrind, Bos taurus (Linné), 1758. Acta Bernensia, Beiträge zur prähistorischen, klassischen und jüngeren Archäologie, 2, 117-196.
Van Vuure, C. 2005. Retracing the Aurochs. History, Morphology and Ecology of an Extinct Wild Ox. Sofia Moscow, Pensoft Publishers.

Zeuner, F.E. 1963. A History of Domesticated Animals. Hutchinson. London.68: CDC12/J'38/101/68; 86: CDC10/H'49/2/86; 87: CDC15/K'39/101/87. Photos taken by Mario Torquemada (M.A.R.). 
